\title{
The In Vivo Effect of Hepatotrophic Factors Augmenter of Liver Regeneration, Hepatocyte Growth Factor, and Insulin-Like Growth Factor-II on Liver Natural Killer Cell Functions
}

\author{
Antonio Francavilla ${ }^{1,3}$, Nikola L. Vujanovic ${ }^{2}$, Lorenzo Polimeno ${ }^{1,3}$, Alessandro \\ Azzarone $^{1,3}$, Angelo lacobellis ${ }^{1,3}$, Albert Deleo ${ }^{2}$, Michio Hagiya ${ }^{4}$, Theresa L. Whiteside ${ }^{2}$, \\ and Thomas E. Starzl ${ }^{1}$ \\ ${ }^{1}$ Department of Surgery and Pittsburgh Transplantation Institute, School of Medicine, University \\ of Pittsburgh, Pittsburgh, PA \\ 2 Department of Pathology and Pittsburgh Cancer Institute, School of Medicine, University of \\ Pittsburgh, Pittsburgh, PA \\ ${ }^{3}$ Department of Gastroenterology, Cl. Medica ${ }^{\circ}$, Universita' degli Studi di Bari, Bari, Italy \\ ${ }^{4}$ Pharmaceuticals Research Center, Toyobo Co., Ltd., Osaka, Japan
}

\begin{abstract}
Fine balanced sequential changes of the levels of circulating hepatotrophic factors are essential for normal liver regeneration. Our recent studies have indicated that liver-resident natural killer (NK) cells are important regulators of liver regeneration and have raised the possibility that hepatotrophic factors might mediate their activities through NK cells. In the present study, we assessed the effects of in vivo administration of three hepatotrophic factors (augmenter of liver regeneration [ALR], insulin-like growth factor-II [IGF-II], and hepatocyte growth factor [HGF]) on NK cells in normal rats. Each of the three, given over a 1-day period in doses known to produce hepatotrophic activity, induced inhibition of NK cell cytotoxic activities in the population of mononuclear leukocytes (MNL) in the liver, but not in MNL from the spleen or peripheral blood. In contrast to these results obtained by the whole animal treatment, the three molecules had no effect on NK cell functions when added to cultures of MNL from the livers, spleens, or blood of untreated rats. These data support and extend our previously advanced hypothesis that ALR and other hepatotrophic factors play an important role in liver regeneration by regional regulation of NK cells through some as-yet-unknown intermediary mechanism.
\end{abstract}

Hepatotrophic factors (Table 1) have been so characterized ${ }^{1-15}$ by virtue of their ability to augment the hyperproliferative response induced by partial hepatectomy $(\mathrm{PH})$ in rats ${ }^{3,6}$ or $\operatorname{dogs},{ }^{5}$ and to prevent the atrophy as well as augment the heightened cell renewal caused by portacaval shunt (Eck's fistula) in dogs. ${ }^{2,4}$ Only two of the eight known hepatotrophic factors (hepatocyte growth factor $[\mathrm{HGF}]$ and transforming growth factor [TGF]- $\alpha$ ) are primary mitogens capable of stimulating de novo hepatocyte proliferation in vitro without the requisite precondition of preexisting commitment to heightened cell renewal. Molecules with opposite effects have been called "antihepatotrophic." $16-18$

After $\mathrm{PH}$, there is an acute temporary increase in the circulating levels of several of the endogenous hepatotrophic factors $1,2,4,5,19$ and multiple gene expression in the liver. ${ }^{20} \mathrm{We}$

Address reprint requests to: Thomas E. Starzl, M.D., Ph.D., Department of Surgery, 3601 Fifth Avenue, 4C Falk Clinic, University of Pittsburgh, Pittsburgh, Pennsylvania, 15213. 
have speculated that the hepatocyte stimulatory activity of augmenter of liver regeneration (ALR) and the other hepatotrophic factors may be mediated through or by nonparenchymal cells. ${ }^{1,9,21}$ This possibility was reinforced by the observation during the acute phase of regeneration after $\mathrm{PH}$ in rats of temporary suppression of natural killer (NK) cell functions of liver mononuclear leukocytes (MNL), followed by their recovery at the termination of regeneration. ${ }^{21}$ These changes occurred contemporaneously with mirror-image susceptibility of the regenerating hepatocytes to NK-induced lysis.

To test this immunologic hypothesis, we have determined in the present study whether the changes of NK cell function occurring after $\mathrm{PH}$ could be reproduced in unoperated naive rats by their treatment with three potent recombinant hepatotrophic factors chosen from the list in Table 1: IGF-II, HGF, and ALR. All three of these systemically administered growth factors were found to mimic all of the changes of spontaneous NK cell functions associated with PH, including the limitation of their effect to liver mononuclear leukocytes (MNL). Because these factors had no effect on cultures of liver MNL from naive rats, additional unknown extra- or intrahepatic mediator(s) may be involved in their hepatic growth regulation.

\section{MATERIALS AND METHODS}

\section{Materials and Assays}

Animals-Male Fischer F344 rats (180-200 g) were purchased from Hilltop Lab Animals, Inc. (Scottdale, PA), and were housed in a specific pathogen-free animal facility of the Pittsburgh Cancer Institute for at least 20 days before the experiments and were fed with standard rat chow and water ad libitum.

Antibodies and Reagents-For phenotyping of rat MNLs, fluorescein isothiocyanatelabeled mouse monoclonal antibodies to rat T-lymphocyte surface antigens including antiCD5 (OX19, immunoglobulin [Ig]G1) from Accurate Chemical and Scientific Corp. (Westbury, NY), and CD3 (G.4.1.A., IgG3) from Bioproducts for Science (Indianapolis, IN) were purchased. Monoclonal antibody against NKR-P1 (3.2.3, IgG1) was raised and conjugated with fluorescein isothiocyanate in our laboratory for the identification of NK cells. IgG isotope control antibodies were purchased from Becton Dickinson (San Jose, CA).

Rat recombinant (r)ALR expressed in transfected COS- 1 cells ${ }^{9}$ and rHGF were gifts from Toyobo Co., Ltd. (Ohtsu, Shiga, Japan), while rIGF-II was purchased from United States Biochemical (Cleveland, $\mathrm{OH}$ ).

Isolation of Rat MNL-Liver, spleen, and blood MNL were isolated and purified, as previously described. ${ }^{21}$ Briefly, liver-resident MNL were isolated, after enzymatic digestion of liver tissue, using metrizamide and Ficoll-Hypaque density gradient centrifugations. MNL from blood and spleen were separated using Ficoll-Hypaque density gradient centrifugations.

Immunofluorescent Staining and Flow Cytometry of MNL-The MNL were adjusted to a concentration of $0.25 \times 10^{6} / 0.2 \mathrm{~mL}$ in phosphate-buffered saline containing $0.1 \%$ (wt/vol) sodium azide and $1 \%$ fetal bovine serum (vol/vol). For direct single-color immunofluorescent staining, the cells were mixed with fluorescein isothiocyanate-labeled mAbs. Cells suspended in phosphate-buffered saline-azide buffer alone or in fluorescein isothiocyanate-conjugated IgG1 monoclonal antibodies $(\mathrm{mAb})$ were used as negative controls. After incubation with the mAbs or reagents at $4^{\circ} \mathrm{C}$ for 30 minutes, the cells were washed two times with phosphate-buffered saline-azide buffer, resuspended in $1 \%$ (wt/vol) paraformaldehyde, and examined by single-color flow cytometry on a FACScan. ${ }^{21}$ Data 
were analyzed using the Reproman computer program (Flow Cytometry Analysis Software for Personal Computers, True Facts Software Inc., Seattle, WA).

\title{
Cytotoxicity Assays
}

A standard 4-hour ${ }^{51} \mathrm{Cr}$-release microcytotoxicity assay was used to quantitate direct cytolytic activity against the NK-sensitive YAC-1 lymphoma cells and NK-resistant P815 mastocytoma cells, as previously described. ${ }^{21}$

Antibody-Dependent Cellular Cytotoxicity-After ${ }^{51} \mathrm{Cr}$-labeling, P815 target cells were preincubated for 15 minutes at room temperature with rat anti-P815 antiserum (a gift of Dr. W.H. Chambers) at a subagglutinating concentration, washed twice, and mixed with the MNL.

Redirected Killing Via NKR-P1-MNL were preincubated with anti-natural killer receptor protein 1 (NKR-P1) $\mathrm{mAb}(0.1 \mu \mathrm{g} / \mathrm{mL})$ at room temperature for 15 minutes. This procedure resulted in sensitization of NK cells in the population of $\mathrm{MNL}$, as a consequence of the specific binding of this mAb to NKR-P1 receptor. The assay was continued by adding to the effector cells ${ }^{51} \mathrm{Cr}$-labeled P815 target cells, which express cell surface Fc receptors and are able to ligate the $\mathrm{Fc}$ portion of anti-NKR-P1 mAb bound to NK cells, and thus to cross-link the NKR-P1 receptor, triggering cytolytic activity of NK cells. ${ }^{22}$ P815 cells preincubated with rat serum obtained before immunization or with a nonreactive $\operatorname{IgG}_{1} \mathrm{mAb}$ served as negative control targets to antibody-dependent cellular cytotoxicity or redirected killing, respectively. Spontaneous release and maximum release were determined by incubating target cells without effectors in medium alone or in 5\% Triton X-100, respectively. The spontaneous release was less than 10\% for both YAC-1 and P815 target cells.

All of the foregoing assays were performed in triplicate. Radioactivity was counted in a gamma counter, and the percentage of specific lysis was determined according to the formula:

$$
\% \text { specific lysis }=\frac{[\text { mean cpm experimental release }- \text { mean } \mathrm{cpm} \text { spontaneous release }]}{[\text { mean cpm maximal release }- \text { mean cpm spontaneous release }]} \times 100
$$

Lytic units (LU) were calculated using a computer program developed by Pross et al. ${ }^{23}$ One lytic unit was defined as the number of effector cells needed to lyse $20 \%$ of $5 \times 10^{3}$ target cells. LU per $10^{7}$ effector cells were calculated on the basis of the following formula:

$$
\frac{\mathrm{LU}_{20} / 10^{7} \mathrm{MNL}}{\% \mathrm{NKR}-\mathrm{P} 1^{\text {bright } \mathrm{MNL}}} \times 100
$$

\section{Experimental Design}

\begin{abstract}
In Vivo Effect of Hepatotrophic Factors on NK Cell Functions of Normal Nonoperated Rats-Four doses of $125 \mathrm{ng}$ rALR or rIGF-II were injected intramuscularly and four doses of 1,000 ng rHGF were given intravenously at 24, 18, 12, and 6 hours before the animals were killed. The animals were killed, and MNL were isolated from peripheral blood, spleen, and liver. The phenotype and cytotoxic activities of MNL were determined.
\end{abstract}

\section{In Vitro Effects of Growth Factors on NK Cells in MNL Populations-}

Suspensions of MNL isolated from the blood, spleen, and liver of normal rats were prepared 
in culture medium (RPMI 1640 plus $10 \%$ fetal bovine serum), which was supplemented with hepatotrophic factors rALR, rIGF-II, and rHGF singly or in combination. The cells were either assessed immediately or after 24 hours of culture at $37^{\circ} \mathrm{C}$. Their cytotoxic activity was tested in the assays described above.

\section{Statistical Analysis}

Statistical significance of the results was calculated using Wilcoxon's signed rank pair and Mann-Whitney $U$ tests. Differences were considered significant at $P<.05$.

\section{RESULTS}

\section{Systemic Administration of Hepatotrophic Factors}

Composition of MNL in the Liver and Peripheral Lymphoid Tissues-The percentages of NKR-P1 $1^{\text {bright }}(\mathrm{NK})$ cells and $\mathrm{CD}^{+}$or $\mathrm{CD}^{+}(\mathrm{T})$ lymphocytes in the liver, spleen, or blood of rats after administration of any of the hepatotrophic factors were not different from the saline controls (Table 2). The failure of treatment to influence changes of the proportions of MNL subpopulations, either in the liver or in the peripheral lymphoid tissues was similar to that after $\mathrm{PH}^{21}$

NK Cell Functions-In contrast to the unchanged phenotype, the rALR, rHGF, and rIGFII had significant and multiple suppressive effects on various NK cell functions (Table 3). The 24-hour pretreatment of normal rats with either of the three hepatotrophic factors induced a rapid suppression of all of the tested spontaneous NK cell functions in liverresident MNL, including direct killing of YAC-1 and P815 target cells, as well as indirect killing, such as antibody-dependent cellular cytotoxicity and NKR-P1-mediated redirected lysis of P815 target cells (Table 3). However, while ALR and IGF-II showed consistent suppressive effects in all experiments performed, as well as in a variety of assays utilized, HGF showed some inconsistency of activity, inducing in one of the experiments a stimulation of NK cytotoxicity against YAC-1 targets and a suppression of spontaneous lymphocyte-activated killing against P815 tumor cells (Table 3). In addition, combined treatment with three hepatotrophic factors showed an inconsistency of effects on liverresident NK cells similar to HGF alone (Table 3). These data suggest that HGF may partially differ from ALR and IGF-II in mechanisms of in vivo induction of functional modulation of liver-resident NK cells, and that, in combined treatment, its effect is dominant.

Neither rALR, rHGF, nor rIGF-II had a significant effect on spleen or blood NK cell killing activities (data not shown).

\section{In Vitro Effects of Hepatotrophic Factors on NK Cell Functions}

To define whether hepatotrophic factor-induced changes in liver-resident NK cells are a consequence of a direct or indirect effect, we added rALR, rHGF, or rIGF-II to cultures of MNL isolated from the livers of untreated rats. The addition of the hepatotrophic factors during the 4-hour ${ }^{51} \mathrm{Cr}$-release cytotoxicity assays did not change spontaneous NK, lymphocyte-activated killer, and antibody-dependent cellular cytotoxicity cytolytic functions or redirected killing (data not shown). Similar data were obtained when liver-resident MNL were preincubated for 24 hours in the presence of any of these hepatotrophic factors (data not shown). 


\section{DISCUSSION}

Liver regeneration following a $\mathrm{PH}$ of $70 \%$ is associated with an increase in serum levels of $\mathrm{ALR}^{1}$ and other growth factors, including HGF, TGF- $\alpha$, and epidermal growth factors, ${ }^{19,24}$ which peak in 12 hours and return almost to baseline by 24 hours. During approximately the same time, rapid and profound suppression of a variety of spontaneous functions of liverresident NK cells has been shown. ${ }^{21}$ In the present study, we showed that the treatment of normal nonoperated rats for 24 hours with exogenous rALR, rHGF, and rIGF-II caused the same liver-restricted changes in NK cell function (Table 4).

The molecules listed in Table 1 prevent in vivo hepatocyte atrophy as well as dramatically up-regulate hepatocyte renewal. For their full expression of a proliferative effect on hepatocytes, these hepatotrophic factors, including that of HGF and TGF- $\alpha$ (which also are considered primary initiators of mitosis in vitro ${ }^{24,25}$ ), require the prior, independent establishment of hyperplasia above resting baseline levels. ${ }^{2-6,10}$ Recognition of the necessity for a priming stimulus underlies the delineation with the Eck fistula ${ }^{2,4,10}$ and minimum hepatectomy models ${ }^{3,5,6}$ used to delineate the major hepatotrophic molecules listed in Table 1. Webber, Godowski, and Fausto ${ }^{26}$ associated the liver priming produced with minimal (30\%) hepatectomy with an increased expression of a variety of protooncogenes, including c-myc.

The demonstrations that TGF- $\beta$ was antihepatotrophic (causing atrophy and hypoplasia) ${ }^{10,16,17}$ and that the serum levels of this cytokine correlated with the events of regeneration ${ }^{17,25,27}$ raised the possibility that TGF- $\beta$ was the turn-off switch that terminated liver volume restoration. The hypothesis that emerged from this collective body of work was that liver growth is regulated by an inter-reactive network of the various autocrine, paracrine, and endocrine factors. ${ }^{1,19}$

Another (and not mutually exclusive) theory is that organ growth is regulated by the immune system. ${ }^{21,28-30}$ This hypothesis was strengthened when the T-cell-directed immunosuppressants, tacrolimus and cyclosporine,,${ }^{11-14}$ which disrupt signal transduction from the T-cell receptor to the nucleus, as well as the recombinant cytosolic binding protein of tacrolimus (FKBP12), ${ }^{15}$ were shown to be potently hepatotrophic. However, the credibility of this hypothesis lost ground when rapamycin, which also is T-cell inhibitory but by a more distal molecular site of action (proximal to the ribosomes), was shown to be potently antihepatotrophic. ${ }^{18}$ Confusing the issue further, T-cell-deficient (nude) rats which have normal liver regeneration following PH, had augmentation of this response by tacrolimus treatment to the same extent as immunologically intact animals. ${ }^{31}$ Because tacrolimus has no effect on the function of isolated spleen NK cells from normal ${ }^{31,32}$ or nude rats both in vivo and in vitro, ${ }^{31}$ the hypothesis by Itoh et al.$^{30}$ that NK cells capped the magnitude of hepatic regeneration was initially discounted by us. ${ }^{31}$ However, in our earlier nude rat studies, the NK cell functions were determined in leukocytes isolated from peripheral lymphoid tissues (i.e., spleen), not from the liver. ${ }^{31}$

Our recently published investigations in normal rats following $\mathrm{PH}$ of $70 \%^{21}$ have provided strong evidence that liver-resident (but not peripheral lymphoid organ) NK cells do in fact undergo sequential functional changes (see Table 4), and are potentially involved not only in the termination of regeneration, as postulated by Itoh et al., ${ }^{30}$ but also in its initiation. The in vivo depletion of NK cells before $\mathrm{PH}$ significantly augmented liver regeneration in normal rats. ${ }^{21}$ These data and those reported herein are compatible with the hypothesis that ALR, HGF, IGF-II, and presumably other hepatotrophic factors produced at the earliest post-PH stage of liver regeneration, are associated with, and may be at least partially responsible for 
the local suppression of liver-resident NK cells. This would allow conversion of the quiescent normal liver to the state of regeneration.

Interestingly, the joint administration of ALR, HGF, and IGF-II to intact animals did not produce the expected synergistic suppressive effect on liver NK cells. The modulation of NK cell functions after combined treatment was similar to that obtained with HGF alone. This finding suggests that simultaneous administration of hepatotrophic factors in optimal doses resulted in competition rather than in synergism. It is possible that, to obtain synergy, it would be necessary to use their sequential administration and different (perhaps smaller) doses than we used. Because hepatotrophic factors showed suppressive effects on NK cells only in vivo and only in the liver, it is conceivable that they indirectly suppress liver NK cells in intact animals by inducing the production of a suppressive factor by cells not present in the purified populations of liver-derived MNL. Congruent with this possibility, it has been shown that $\mathrm{ALR}^{33}$ as well as IGF-II ${ }^{34,35}$ selectively accumulate in liver sinusoids and possibly bind to the sinusoid lining (endothelial) cells, which also represent the major cells in the liver interacting with and binding liver-resident NK cells. In addition, liver sinusoid endothelial cells have been shown during post-PH liver regeneration to be early producers of TGF- $\beta, 17$ a powerful antihepatotrophic and immunosuppressive cytokine. ${ }^{16,17,26}$ Thus, ALR as well as other hepatotrophic factors may exercise their suppressive effect on NK cells by binding to and inducing liver sinusoid endothelial cells to produce TGF- $\beta$. The implication is that hepatotrophic and antihepatotrophic factors (see Table 1) have a complex, coordinated, physiological effect.

Mesenchymal-epithelial interactions have been proposed as the essential governance mechanism of embryonal organ morphogenesis, epithelial differentiation, and tissue remodelling, of which hepatic regeneration is a prime example in mature mammals. Such speculation is supported by circumstantial evidence from tissue culture technology ${ }^{36}$ and more recently from molecular studies of HGF (scatter factor). ${ }^{37}$ Regeneration responses, including those following unilateral duct ligation and $\mathrm{PH},{ }^{38}$ could be explained most easily by endocrine communication or, alternatively, by the migration and in situ activity of various hematolymphopoietic cell lineages, including NK cells. ${ }^{21,39,40}$

\section{Acknowledgments}

Supported by Project Grant No. DK 29961 from the National Institutes of Health, Bethesda, MD; research grants from the Veterans Administration Medical Center; and the Consiglio Nazionale delle Ricerche ACRO Program Grant 95.00364.PF39.

\section{Abbreviations}

$\begin{array}{ll}\text { PH } & \text { partial hepatectomy } \\ \text { HGF } & \text { hepatocyte growth factor } \\ \text { TGF } & \text { transforming growth factor } \\ \text { ALR } & \text { augmenter of liver regeneration } \\ \text { NK } & \text { natural killer } \\ \text { MNL } & \text { mononuclear leukocytes } \\ \text { IGF-II } & \text { insulin-like growth factor-II } \\ \text { Ig } & \text { immunoglobulin } \\ \text { NKR-P1 } & \text { natural killer receptor protein 1 }\end{array}$


mAbs monoclonal antibodies

LU lytic unit

\section{References}

1. Francavilla A, Hagiya M, Porter KA, Polimeno L, Ihara I, Starzl TE. Augmenter of liver regeneration (ALR): its place in the universe of hepatic growth factors. Hepatology 1994;20:747757. [PubMed: 8076931]

2. Starzl TE, Porter KA, Putnam CW. Intraportal insulin protects from the liver injury of portacaval shunt in dogs. Lancet 1975;2:1241-1246. [PubMed: 53727]

3. LaBreque DR, Pesch LA. Preparation and partial characterization of hepatic regenerative stimulator substance (HSS) from rat liver. J Physiol 1975;248:272-284.

4. Starzl TE, Jones AF, Terblanche J, Usui S, Porter KA, Mazzoni G. Growth-stimulating factor in regenerating canine liver. Lancet 1979;1:127-130. [PubMed: 84151]

5. Terblanche J, Porter KA, Starzl TE, Moore J, Patzelt L, Hayashida N. Stimulation of hepatic regeneration after partial hepatectomy by infusion of a cytosol extract from regeneration dog liver. Surg Gynecol Obstet 1980;151:538-544. [PubMed: 6998027]

6. Francavilla A, Ove P, Polimeno L, Coetzee M, Makowka L, Rose J, Van Thiel DH, et al. Extraction and partial purification of a hepatic stimulatory substance in rats, mice and dogs. Cancer Res 1987;47:5600-5605. [PubMed: 3664466]

7. Francavilla A, Barone M, Van Thiel DH, Mazzaferro V, Prelich JG, Starzl TE. Further steps of hepatic stimulatory substance purification. Dig Dis Sci 1991;36:674-680. [PubMed: 2022170]

8. Francavilla A, Polimeno L, Barone M, Azzarone A, Starzl TE. Hepatic regeneration and growth factors. J Surg Oncol Suppl 1993;3:1-7. [PubMed: 7684910]

9. Hagiya M, Francavilla A, Polimeno L, Ihara I, Sakai H, Seki T, Shimonishi M, et al. Cloning and sequence analysis of the rat augmenter of liver regeneration (ALR) gene: expression of biology active recombinant ALR and demonstration of tissue distribution. Proc Natl Acad Sci U S A 1994;91:8142-8146. [PubMed: 8058770]

10. Francavilla A, Starzl TE, Porter K, Scotti-Foglieni C, Michalopoulos GK, Carrieri G, Trejo J, et al. Screening for candidate hepatic growth factors by selective portal infusion after canine Eck's fistula. Hepatology 1991;14:665-670. [PubMed: 1916668]

11. Makowka L, Svanas G, Esquivel C, Venkataramanan R, Todo S, Iwatsuki S, Van Thiel D, et al. Effect of cyclosporine on hepatic regeneration. Surg Forum 1986;37:353-354.

12. Mazzaferro V, Porter KA, Scotti-Foglieni CL, Venkataramanan R, Makowka L, Rossaro L, Francavilla A, Todo S, et al. The hepatotrophic influence of cyclosporine. Surgery 1990;107:533539. [PubMed: 2185568]

13. Francavilla A, Barone M, Todo S, Zeng Q, Porter KA, Starzl TE. Augmentation of rat liver regeneration by FK 506 compared with cyclosporine. Lancet 1989;1:1248-1249. [PubMed: 2479802]

14. Starzl TE, Porter KA, Mazzaferro V, Todo S, Fung J, Francavilla A. Hepatotrophic effects of FK 506 in dogs. Transplantation 1991;51:67-70. [PubMed: 1702912]

15. Starzl TE, Schrieber SL, Albers MW, Porter KA, Foglieni CS, Francavilla A. Hepatotrophic properties in dogs of human FKBP, the binding protein for FK506 and rapamycin. Transplantation 1991;52:751-753. [PubMed: 1718068]

16. Francavilla A, Azzarone A, Carrieri G, Scotti-Foglieni C, Zeng QH, Cillo U, Porter K, et al. Effect on the canine eck fistula liver of intraportal TGF- $\beta$ alone or with hepatic growth factors. Hepatology 1992;16:1267-1270. [PubMed: 1427665]

17. Braun L, Mead JE, Panzica M, Mikumo R, Bell GI, Fausto N. Transforming growth factor- $\beta$ mRNA increases during liver regeneration: a possible paracrine mechanism of growth regulation. Proc Nat Acad Sci U S A 1988;85:1539-1543. 
18. Francavilla A, Starzl TE, Scotti C, Carrieri C, Azzarone S, Zeng QH, Porter KA, et al. Inhibition of liver, kidney, and intestine regeneration by rapamycin. Transplantation 1992;53:496-498. [PubMed: 1371198]

19. Fausto N, Laird AD, Webber EM. Role of growth factors and cytokines in hepatic regeneration. FASEB J 1995;9:1527-1536. [PubMed: 8529831]

20. Mohn K, Laz TM, Hsu J-C, Melby AE, Bravo R, Taub R. The immediate early-growth response in regenerating liver and insulin-stimulated H-35 cells: comparison with serum-stimulated 3T3 cells and identification of 41 novel immediate-early genes. Mol Cell Biol 1991;11:381-390. [PubMed: 1986233]

21. Vujanovic NL, Polimeno L, Azzarone A, Francavilla A, Chambers WH, Starzl TE, Herberman RB, et al. Changes of liver-resident natural killer cells during liver regeneration in rats. J Immunol 1995;154:6324-6338. [PubMed: 7759871]

22. Giorda R, Rudert WA, Vavassori C, Chambers WH, Hiserodt JC, Trucco M. NKR-P1, a signal transduction molecule on natural killer cells. Science 1990;249:1298. [PubMed: 2399464]

23. Pross HF, Baines GM, Rubin P, Shragge P, Patterson MS. Spontaneous human lymphocyte mediated cytotoxicity against tumor target cells. IX. The quantitation of natural killer cell activity. J Clin Immunol 1981;1:51-63. [PubMed: 7334070]

24. Michalopoulos G. Liver regeneration and growth factors: Old puzzles and new perspectives. Labor Invest 1992;67:413-415.

25. Fausto N, Mead JE. Regulation of liver growth: protooncogenes and transforming growth factors. Lab Invest 1989;60:4-13. [PubMed: 2642989]

26. Webber EM, Godowski PJ, Fausto N. In vivo response of hepatocytes to growth factors requires an initial priming stimulus. Hepatology 1994;19:489-497. [PubMed: 8294105]

27. Fausto, N. Hepatic regeneration. In: Zakim, D.; Boyer, TD., editors. Hepatology: A Textbook of Liver Disease. Philadelphia: Saunders; 1990. p. 49-64.

28. Flye MW, Yu S. Augmentation of cell-mediated cytotoxicity following 50\% partial hepatectomy. Transplantation 1990;49:581-587. [PubMed: 2316018]

29. Sato Y, Tsukada K, Hai T, Ohmori K, Toshida K, Muto T, Watanabe H. Activation of extrathymic $\mathrm{T}$ cells in the liver during liver regeneration following partial hepatectomy. Immunology 1993;78:86-91. [PubMed: 8436406]

30. Itoh H, Abo T, Sugawara S, Kanno A, Kumagai K. Age-related variation in the proportion and activity of murine liver natural killer cells and their cytotoxicity against regenerating hepatocytes. J Immunol 1988;141:315-323. [PubMed: 3379309]

31. Francavilla A, Starzl TE, Barone M, Zeng Q-H, Porter KA, Zeevi A, Markus PM, et al. Studies on mechanisms of augmentation of liver regeneration by cyclosporine and FK 506. Hepatology 1991;14:140-143. [PubMed: 1712337]

32. Markus PM, Van den Brink MRM, Luchs BA, Fung JJ, Starzl TE, Hiserodt JC. Effects of in vivo treatment with FK506 on natural killer cells in rats. Transplantation 1991;51:913-915. [PubMed: 1707562]

33. Newton E, Chyung Y, Kang P, Bucher N, Andrews D, Kurnick J, DeLeo A, et al. The immunofluorescence visualization of ALR (augmenter of liver regeneration) reveals its presence in platelets and male germ cells. J Histochem Cytochem. in press.

34. Han VKM, D’Ercole J, Lund PK. Cellular localization of somatomedin (insulin-like growth factor) messenger RNA in the human fetus. Science 1987;236:193-197. [PubMed: 3563497]

35. Han VKM, Hill DJ, Strain AJ, Towle AC, Lauder JM, Underwood LE, D'Ercole J. Identification of somatomedin/insulin-like growth factor immunoreactive cells in the human fetus. Pediatr Res 1987;22:245-249. [PubMed: 3309857]

36. Grobstein C. Mechanisms of organogenetic tissue interaction. United States National Cancer Institute Monograph 1967;26:279-299.

37. Sonnenberg E, Meyer D, Weidner KM, Birchmeier C. Scatter factor/hepatocyte growth factor and its receptor, the c-met tyrosine kinase, can mediate a signal exchange between mesenchyme and epithelia during mouse development. J Cell Biol 1993;123:223-235. [PubMed: 8408200] 
38. Polimeno L, Azzarone A, Zeng QH, Panella C, Subbotin W, Carr B, Bouzahzah B, et al. Cell proliferation and oncogene expression after bile duct ligation in the rat: evidence of a specific growth effect on bile duct cells. Hepatology 1995;21:1070-1078. [PubMed: 7705781]

39. Murase N, Starzl TE, Ye Q, Tsamandas A, Thomson AW, Rao AS, Demetris AJ. Multilineage hematopoietic reconstitution of supralethally irradiated rats by syngeneic whole organ transplantation: with particular reference to the liver. Transplantation 1996;61:1-4. [PubMed: 8560546]

40. Starzl TE, Demetris AJ, Murase N, Trucco M, Thomson AW, Rao AS. The lost chord: Microchimerism and allograft survival. Immunol Today 1996;17:577-584. [PubMed: 8991290] 
Table 1

Growth Factors Revealed by Studies In Eck Fistula Models (1995)

\begin{tabular}{|c|c|}
\hline Growth Factors & Reference \\
\hline \multicolumn{2}{|l|}{ Stimulatory } \\
\hline \multicolumn{2}{|l|}{ Hormones: } \\
\hline Insulin & Starzl $^{2}$ \\
\hline \multicolumn{2}{|l|}{ Growth Factors: } \\
\hline Cytosol protein fractions or ALR & Francavilla $1,6-8 ;$ Starzl $^{2,4} ;$ LaBreque $^{3}$; Terblanche $^{5}$; Hagiya 9 \\
\hline IGF-II & Francavilla 10 \\
\hline TGF- $\alpha^{*}$ & Francavilla 10 \\
\hline $\mathrm{HGF}^{*}$ & Francavilla 10 \\
\hline \multicolumn{2}{|l|}{ Immunosuppressants } \\
\hline Cyclosporine & Makowka $^{11}$; Mazzaferro ${ }^{12}$ \\
\hline FK506 & Francavilla $^{13} ;$ Starzl $^{14}$ \\
\hline \multicolumn{2}{|l|}{ Immunophilins } \\
\hline $\mathrm{FKBP}_{12}$ & Starzl 15 \\
\hline \multicolumn{2}{|l|}{ Inhibitory } \\
\hline \multicolumn{2}{|l|}{ Growth factors: } \\
\hline TGF- $\beta^{\dagger}$ & Francavilla ${ }^{16}$; Braun 17 \\
\hline \multicolumn{2}{|l|}{ Immunosuppressants } \\
\hline Rapamycin $^{\dagger}$ & Francavilla 18 \\
\hline
\end{tabular}


Table 2

Phenotype of Liver, Spleen, and Blood MNL Obtained From Rats Following 24-Hour Treatment With Hepatotrophic Factors

\begin{tabular}{llc}
\hline Source of MNL & CD5 $^{+}$(T) Cells & NKR-P1 $^{\text {bright }}$ (NK) Cells \\
\hline Liver & & \\
$\quad$ Vehicle (control) & $25 \pm 11$ & $34 \pm 9$ \\
ALR & $23 \pm 8$ & $33 \pm 10$ \\
IGF-II & $25 \pm 7$ & $32 \pm 11$ \\
HGF & $28 \pm 9$ & $31 \pm 8$ \\
Spleen & & \\
Vehicle (control) & $57 \pm 8$ & $8 \pm 2$ \\
ALR & $52 \pm 5$ & $10 \pm 1$ \\
IGF-II & $55 \pm 4$ & $9 \pm 2$ \\
HGF & $56 \pm 4$ & $11 \pm 2$ \\
Blood & & \\
Vehicle (control) & $85 \pm 4$ & $6 \pm 9$ \\
ALR & $77 \pm 6$ & $13 \pm 7$ \\
IGF-II & $88 \pm 7$ & $9 \pm 4$ \\
HGF & $83 \pm 5$ & $12 \pm 3$ \\
\hline
\end{tabular}

NOTE. Data are means \pm SEM of percentages of total MNL in liver, spleen, and blood cells. Flow cytometry analysis of MNL was performed after immunostaining with fluorescein isothiocyanate-labeled anti-CD5, anti-CD3 (data not shown, similar to that obtained with anti-CD5) or antiNKR-P1 mAbs, as described in Materials and Methods. Three animals contributed to each experiment. rALR or rIGF-II $(0.5 \mu \mathrm{g})$ and $\mathrm{rHGF}(4.0 \mu \mathrm{g})$ were the total doses of the growth factors injected per individual animal during 24 hours. 
Table 3

In Vivo Effects of rALR, rHGF, and rIGF-II on Cytolytic Functions of Liver-Resident NK Cells

\begin{tabular}{|c|c|c|c|}
\hline Effectors & Targets (Cytotoxicity) & $\mathbf{L U}_{20} / 10^{7} \mathrm{NK}$ & $\%$ Modulation \\
\hline \multicolumn{4}{|l|}{ Experiment 1} \\
\hline Vehicle (Control) & YAC-1 (NK) & 193.3 & 0 \\
\hline ALR & & 125.3 & -35 \\
\hline HGF & & 140.2 & -27 \\
\hline IGF-II & & 115.1 & -40 \\
\hline Vehicle (control) & P815 (LAK) & 15.4 & 0 \\
\hline ALR & & 9.9 & -36 \\
\hline HGF & & 6.2 & -60 \\
\hline IGF-II & & 4.3 & -70 \\
\hline Vehicle (control) & $\mathrm{P} 815+\alpha \mathrm{P} 815$ Abs (ADCC) & 376.0 & 0 \\
\hline ALR & & 261.6 & -29 \\
\hline HGF & & 237.4 & -35 \\
\hline IGF-II & & 138.1 & -62 \\
\hline Vehicle (control) & $\mathrm{P} 815+\alpha$ NKR-P1 mAb (redirected) & 48.3 & 0 \\
\hline ALR & & 44.2 & -9 \\
\hline HGF & & 28.6 & -40 \\
\hline IGF-II & & 36.7 & -24 \\
\hline \multicolumn{4}{|l|}{ Experiment 2} \\
\hline Vehicle (control) & YAC-1 (NK) & 501.6 & 0 \\
\hline ALR & & 333.1 & -34 \\
\hline HGF & & 574.8 & +15 \\
\hline IGF-II & & 418.5 & -17 \\
\hline ALR +HGF + IGF-II & & 606.5 & +20 \\
\hline Vehicle (control) & P815 (LAK) & 53.8 & 0 \\
\hline ALR & & 26.1 & -45 \\
\hline IGF-II & & 31.6 & -41 \\
\hline HGF & & 37.6 & -30 \\
\hline ALR +HGF + IGF-II & & 41.1 & -24 \\
\hline
\end{tabular}

NOTE. Liver-resident MNL were isolated from vehicle (control)-, rALR-, rHGF-, or rIGF-II-treated animals for 24 hours and were assessed for their cytotoxicity using various assays, as described in Materials and Methods. Data represent $\mathrm{LU}_{20} / 10^{7} \mathrm{NK}$ cells calculated on the basis of the triplicate mean percentages of MNL killing in four different effector:target ratios, and the percentage of NKR-PI ${ }^{\text {bright }}(\mathrm{NK})$ cells, determined by flow cytometry. ${ }^{21}$ Results are from two experiments ( $\mathrm{n}=3$ per group).

Abbreviations: LAK, lymphocyte-activated killer; ADCC, antibody-dependent cellular cytotoxicity. 
Table 4

Changes of Spontaneous NK Cell Functions Following PH or Hepatotrophic Factor Treatment in Rats

\begin{tabular}{lcccc}
\hline & Following PH & & \multicolumn{2}{c}{ Following Hepatotrophic Factors } \\
\cline { 2 - 2 } \cline { 5 - 5 } Cell Functions & $\mathbf{3}$ h to 14 d & & $\mathbf{2 4}$ h In Vivo & In Vitro \\
\hline YAC-1 lysis & DF & DF & NC \\
P815 lysis & DF & DF & NC \\
ADCC & DF & DF & NC \\
Redirected lysis & DF & DF & NC \\
\hline
\end{tabular}

NOTE. The summary of PH effects is from our previous publication ${ }^{21}$ and that after treatments with hepatotrophic factors from the present study. Abbreviations: DF, decrease of function; NC, no change of function; ADCC, antibody-dependent cellular cytotoxicity. 